\title{
Genotoxicity of citrus wastewater in prokaryotic and eukaryotic cells and efficiency of heterogeneous photocatalysis by $\mathrm{TiO}_{2}$
}

\author{
Marghereth Saverini ${ }^{a}$, Irene Catanzaro ${ }^{a}$, Giulia Sciandrello ${ }^{\mathrm{a}, *}$, Giuseppe Avellone ${ }^{\mathrm{a}}$, Sergio Indelicato ${ }^{\mathrm{a}}$, \\ Giuseppe Marcì ${ }^{\mathrm{b}, \mathrm{c}}$, Leonardo Palmisano ${ }^{\mathrm{b}, \mathrm{c}}$ \\ a Dipartimento di Scienze e Tecnologie Molecolari e Biomolecolari (STEMBIO), Università di Palermo, Italy \\ ${ }^{\mathrm{b}}$ Dipartimento di Ingegneria Elettrica, Elettronica e delle Telecomunicazioni, di tecnologie Chimiche, Automatica e modelli Matematici (DIEETCAM), Università di Palermo, Italy \\ ${ }^{\mathrm{c}}$ Consorzio Interuniversitario la Chimica per l'Ambiente (INCA), Marghera, Italy
}

\section{A R T I C L E I N F O}

\section{Article history:}

Received 26 July 2011

Received in revised form 27 October 2011

Accepted 6 December 2011

Available online 17 December 2011

\section{Keywords:}

Citrus wastewater

Ames test

Comet assay

$\mathrm{TiO}_{2}$ photocatalysis

\begin{abstract}
A B S T R A C T
The presence of $( \pm) \alpha$-pinene, $(+) \beta$-pinene, $(+) 3$-carene, and $R-(+)$ limonene terpenes in wastewater of a citrus transformation factory was detected and analyzed, in a previous study, by using Solid Phase Microextraction (SPME) followed by GC analyses. Purpose of that research was to compare the genotoxic responses of mixtures of terpenes with the genotoxicity of the individual compounds, and the biological effects of actual wastewater. Genotoxicity was evaluated in the Salmonella reversion assay (Ames test) and in V79 cells by Comet assay. Ames tests indicated that the four single terpenes did not induce an increase of revertants frequency. On the contrary, the mixtures of terpenes caused, in the presence of metabolic activation, a highly significant increase of the revertants in TA100 strain in comparison to the control. The Comet assay showed a significant increase in DNA damage in V79 cells treated for $1 \mathrm{~h}$ with single or mixed terpenes. Moreover, the actual wastewater was found highly genotoxic in bacterial and mammalian cells. Photocatalytic tests completely photodegraded the pollutants present in aqueous wastewater and the initial high genotoxicity of samples of wastewater collected during the photocatalytic run, was completely lose in $3 \mathrm{~h}$ of irradiation.
\end{abstract}

(c) 2011 Elsevier B.V. All rights reserved.

\section{Introduction}

The cultivation of oranges is an important industry and a significant component of the economy of Mediterranean countries. Citrus wastewater derives from the production of citrus juice and the extraction of essential oils as byproduct. This type of effluent is characterized by very high organic loads (BOD: 20-1400 mg/l; COD: $100-2000 \mathrm{mg} / \mathrm{l}$ ), by high variability of low values of $\mathrm{pH}$, by the presence of low concentrations of nutrients (especially nitrogen and phosphorus) and flavonoids and heteropolysaccharides, as for instance hesperidin and pectin, in colloidal form. Another peculiarity of the citrus effluent is the presence of essential oils in highly variable concentrations that can lead to serious interferences during the preparation of activated sludge commonly used in the treatment of the industrial wastewater. Indeed $\mathrm{pH}$ must fall within the range of values from 6.0 to 8.5 to accelerate the biological processes and to ensure the occurrence of sedimentation of the mud; high concentrations of COD in the citrus effluent require high amounts of nutrients, which could lead to exceed the concentration limits prescribed by the regulations; essential oils, which through their bacteriostatic action [1] can significantly slow down

\footnotetext{
* Corresponding author. Tel.: +39 09123897332; fax: +39 0916577347.

E-mail address: giulia.sciandrello@unipa.it (G. Sciandrello).
}

or block the intensive processes [2], can prevent sedimentation of the sludge when they are present at concentrations above $50 \mathrm{ppm}$ [3]. Recently, citrus processing wastewater were evaluated using toxicity bioassays on aquatic macroinvertebrates and using biochemical biomarkers and it was classified as toxic [4]. The composition of citrus transformation plant wastewater is highly complex, and the toxicity can be due to the high concentration of organics, including the terpenes, the major constituents of essential oils [4].

The terpenes are secondary metabolites produced from carbon photosynthesis and are involved in the attraction of pollinators and in the defense against insects, herbivores and microbes [57]. They are industrially used in foods and in cleaning products. Only few conflicting studies exist [8-10] on the biological effects of essential oils and terpenes.

In a previous paper, we have evaluated the toxicity of $( \pm)-\alpha-$ pinene, $(+)-\beta$-pinene, $\mathrm{R}-(+)$ limonene, $(+) 3$-carene, that are some of the most important terpenes present in a citrus essential oil and were found in high concentrations in actual industrial effluents. The mixture of four terpenes, but not the single terpenes, induced gene mutations in V79 Hamster Chinese cells [11].

The main aim of the present study was to compare the genotoxic responses of the four terpenes with the genotoxicity of their mixtures in the Salmonella reversion test and in V79 Hamster Chinese cells by Comet assay. Synthetic solutions of each terpene 
at concentrations identical to those found in actual effluents were used.

Notably these types of actual effluents contain not only terpenes but also many other compounds and some of them are unknown; moreover, information about their genotoxicity is scarce. For this reason we have also studied the biologic effects in Salmonella typhimurium and in V79 Hamster Chinese cells of the actual aqueous effluents.

The incomplete removal of persistent organic species observed after the conventional wastewater treatment, prompted us to verify, by performing Total Organic Carbon (TOC) analyses, if heterogeneous photocatalysis could be successfully applied as a coupled technology to the purification of this type of actual effluents. This method has been widely used for complete degradation of several organic pollutants [12-14] and in particular for terpenes present in actual effluents [11]. Moreover experiments were carried out to verify if the photocatalytic treatment influences the genotoxicity of the effluents. In this regards Ames tests have been performed by using samples withdrawn at different times during the photocatalytic runs.

\section{Materials and methods}

\subsection{Chemicals}

$( \pm) \alpha$-Pinene, $(+) \beta$-pinene, $(+) 3$-carene, and R-(+)limonene were purchased from Sigma-Aldrich. For the biological study fresh solutions were prepared by dissolving each terpene in a bacterial nutrient broth or in a mammalian medium (D-MEM) supplemented with $0.5 \%$ DMSO (Sigma), while methanolic solutions were prepared for the analytical study. All standard reagents used, namely, terpinel-4-olo, caryophyllene, neryl acetate, $\beta$-citronellol, transgeraniol, were purchased from Fluka (Buchs, Switzerland). Mix hydrocarbons from C10 to C26, used only to calculate LRI (Linear Retention Index) of monoterpenes identified, was purchased from Supelco.

\subsection{Wastewater samplings}

Samples were collected in a citrus fruit transformation factory that utilizes activated sludge treatments to purify wastewater. The types of aqueous effluents studied were: untreated (B) and treated (C) wastewater. Three samples of both B and C effluents were collected at each sampling location during the period of activity of the factory in 2008 and 2010.

\subsection{HS-SPME-GC/FID analysis}

The combination of HS-SPME-GC/FID [15,16] offers high instrumental sensitivity allowing for the simultaneous identification and quantification of each terpene both in the industrial and synthetic samples. The extraction procedure as the choice of PDMS (polydimethylsiloxane) fiber, adsorption and desorption times $[17,18]$ were the same optimized in 2008 [11].

For each sample three SPME extractions and desorptions were realized. All the analyses of the synthetic solutions and the linear calibration plots ( $R$ between 0.993 and 0.999 ) were performed using stock solutions obtained by diluting the four standards methanolic terpenes solutions $(200 \mathrm{ppm})$ in ultrapure water to concentrations ranging between 5 and $500 \mathrm{ppb}$ (standard deviation $<15 \%$ ), with addition of neryl acetate as the internal standard (IS). The limit of detection (LOD) was fixed between 1 and $3 \mathrm{ppb}$, i.e. when the signal was three times higher than the noise. Conversely, the limit of quantization (LOQ) was fixed between 3 and $5 \mathrm{ppb}$, i.e. when the signal was 10 times higher than the noise.
Chromatographic analyses were performed on a Shimadzu GC 2010A equipped with a Supelcowax (CW) column (Supelco) $30 \mathrm{~m}$ long, $0.25 \mathrm{~mm}$ I.D., $2.5 \mu \mathrm{m}$ thick and a FID detector. A temperature programme from $60^{\circ} \mathrm{C}$ (maintained for $3 \mathrm{~min}$ ) to $130^{\circ} \mathrm{C}$ with $15^{\circ} \mathrm{C} / \mathrm{min}$ ramp rate and then to $240^{\circ} \mathrm{C}$ (maintained for $1 \mathrm{~min}$ ) was set. The linear velocity of the carrier gas (He, 99.9995\%) was fixed at $25.9 \mathrm{~cm} / \mathrm{s}$. The FID temperature was set at $250{ }^{\circ} \mathrm{C}$.

\subsection{HS-SPME-GC/MS analyses}

The sampling by HS-SPME was identical to GC/FID. Analyses were performed using a Thermo Fisher Scientific GC/MS equipment using a Focus GC, coupled with a quadrupole DSQ II mass spectrometer. Separation of compounds was carried out with the same Supelcowax column and gas chromatographic method of GC/FID analysis. The identical linear velocities of $25.9 \mathrm{~cm} / \mathrm{s}$ was set for GC/FID and GC/MS, while the transfer line temperature was set at $200{ }^{\circ} \mathrm{C}$.

Electron impact mass spectra were recorded at $70 \mathrm{eV}$ ionization energy in the 35.0-450.0 dalton mass range at $2 \mathrm{scan} / \mathrm{s}$; the quadrupole temperature was set at $225^{\circ} \mathrm{C}$.

Collected data were processed with the instrument data system and chromatographic and spectrometric results showed excellent reproducibility ( $\mathrm{SD} \leqslant 4 \%$ ). Each determination was repeated three times.

\subsection{Ames tests}

The Ames tests were performed by plate incorporation procedure as previously described [19]. S. typhimurium strain TA100 was grown in $20 \mathrm{ml}$ nutrient broth (Oxoid no 2) with ampicillin $(0.1 \mathrm{ml}$ of $8 \mathrm{mg} / \mathrm{ml}$ ampicillin solution, Sigma-Aldrich) in a shaking incubator at $37^{\circ} \mathrm{C}$ until the suspension reached a density of about $10^{9}$ cells/ml (measured as absorbance at $650 \mathrm{~nm}$ ). This suspension $(100 \mu \mathrm{l})$ was added to $2 \mathrm{ml}$ molten overlayer agar (supplemented with $18 \%$ glucose and $0.2 \mathrm{ml}$ of $0.5 \mathrm{mM}$ histidine/biotin solution) together with aqueous solutions of the single terpenes or the mixture of four terpenes in the absence or in the presence of $500 \mu \mathrm{l} \mathrm{S9}$ (10\%) mix and poured onto minimal-agar petri dishes. The solutions, prepared separately for each terpene at the concentrations corresponding to those present in the wastewater B (untreated) and C (treated) sampled in 2008 [11], were used individually or concurrently. The inverted plates were held at $37^{\circ} \mathrm{C}$ in a dark incubator for $48 \mathrm{~h}$ and then the revertant colonies were scored. The strain was tested without addition of foreign compounds as the negative control and with $1 \mu \mathrm{g} /$ plate methyl methane sulfonate (MMS, CAS 66273 Sigma-Aldrich) as the positive control. Moreover, increasing doses $(0,10,20,50$, and $100 \mu \mathrm{l} /$ plate $)$ of actual wastewater B or C (sampled in 2010), filtered by passing through $0.45 \mu \mathrm{m}$ filters, were tested with the same procedure above described. Each determination was carried out in triplicate and two independent experiments were carried out at least.

Samples $(100 \mu \mathrm{l} /$ plate $)$ collected every hour during the photocatalytic degradation of wastewater $C$ were tested with the same procedure.

For metabolic activation, S9 mix was prepared on ice immediately before its usage by adding solutions of phosphate buffer at $\mathrm{pH}$ 7.4, NADP, G-6-P, $\mathrm{KCl}$ and $\mathrm{MgCl}_{2}$ up to final concentrations of $0.1 \mathrm{M}, 4,6,8,33 \mathrm{mM}$, respectively. Subsequently $10 \%$ rat liver S9 (Araclor-1254 induced, Trinova Biochem.) was added.

A sample was considered mutagenic when an increase of the number of revertants up to the double with respect to the negative control was reached. The number of spontaneous revertants ranged between 100 and 200 for strain TA100, under the experimental conditions used. 


\subsection{Cell line}

V79 Chinese hamster cells were cultured in D-MEM (Gibco, Invitrogen), supplemented with $5 \%$ foetal calf serum (Invitrogen), penicillin $(100 \mathrm{U} / \mathrm{ml})$ and streptomycin $(100 \mu \mathrm{g} / \mathrm{ml})$ and maintained at $37{ }^{\circ} \mathrm{C}$ in a $5 \% \mathrm{CO}_{2}$ humidified incubator.

\subsection{Viability}

Viability of V79 Chinese hamster cells was evaluated after $1 \mathrm{~h}$ treatment both in the presence of synthetic solutions containing the single terpenes, used individually or concurrently, or in the presence of actual effluents filtered by passing through $0.45 \mu \mathrm{m}$ filters, with trypan blue dye. This dye is normally taken up by nonviable cells but not by viable cells because it only penetrates through membranes of damaged cells. Treated and untreated cells were stained for 5 min with $0.4 \%$ trypan blue (Sigma-Aldrich), and counted using a Burker chamber under a light microscope with a $20 \times$ magnification. Cell viability was expressed as the percentage of viable cells compared to the total number of cells counted.

\subsection{Comet assay}

The alkaline single cell gel electrophoresis (SCGE) assay, also known as Comet assay, was carried out according to the protocol of Singh and McCoy [20]. After $24 \mathrm{~h}$ of growth, V79 Chinese hamster cells were exposed for $1 \mathrm{~h}$ to the single terpene or concurrently to the four terpenes at concentrations corresponding to those found in actual wastewater B (untreated) and C (treated) sampled in 2008 [11] or to $100 \mu \mathrm{l} /$ plate of actual wastewater B, and C sampled in 2010 and filtered by passing through $0.45 \mu \mathrm{m}$ filters. After exposure, the cells were washed twice with Hanks' salt solution and collected by trypsinization. Because the viability of cells after treatment, determined by trypan blue dye, was always $\geqslant 70 \%$ [21], the cells were immediately processed in the SCGE assay. They were centrifuged at $800 \mathrm{rpm}$ for $10 \mathrm{~min}$, re-suspended in PBS $\left(2 \times 10^{5}\right.$ cells $/ 10 \mu$ l final concentration) and mixed with $65 \mu \mathrm{l}$ of $0.7 \%$ Low Melting Agarose (LMA, Bio-Rad). Subsequently they were layered on a slide (GelBond film, Sigma), previously coated with a layer of 0.5\% Normal Melting Agarose (NMA, Fisher Molecular Biology), and covered with another layer of LMA. The agarose suspension was covered with a coverslip and placed at $4{ }^{\circ} \mathrm{C}$ for $10 \mathrm{~min}$. The coverslip was gently removed and the slide was submersed into lysing solution $(2.5 \mathrm{M} \mathrm{NaCl}, 100 \mathrm{mM} \mathrm{Na} 2$ EDTA, $10 \mathrm{mM}$ Tris, $10 \%$ DMSO, $1 \%$ Triton X-100, pH 10.0) for $1 \mathrm{~h}$ under dark at $4{ }^{\circ} \mathrm{C}$. After lysis the slides were placed for $15 \mathrm{~min}$ in a horizontal electrophoresis gel tray containing fresh alkaline buffer $(300 \mathrm{mM} \mathrm{NaOH}$, $1 \mathrm{mM} \mathrm{Na}{ }_{2}$ EDTA, $\mathrm{pH}>8$ ) and then subjected to an electric field of $0.7 \mathrm{~V} / \mathrm{cm}$ in the dark at $4^{\circ} \mathrm{C}$ for $20 \mathrm{~min}$. Following electrophoresis the microgels were neutralized in $0.4 \mathrm{M}$ Tris- $\mathrm{HCl}$ ( $\mathrm{pH} 7.5)$, dehydrated in methanol for $2 \mathrm{~min}$ and allowed to dry at room temperature. The DNA was stained with ethidium bromide $(2 \mu \mathrm{g} / \mathrm{ml})$ (Electran $\mathrm{BDH}$ ), and visually examined by fluorescence microscope (Nikon Microphot-FXA/SA), equipped with a HBO 100 mercury lamp and a suitable filter. Photomicrographs were processed using Photoshop 6.0 Software (Adobe). For qualitative evaluation, at least 1000 cells were scored for each dose. Cells were classified as undamaged, damaged with Comet shape and ghosts with small head and large tails. DNA damage was quantified by tail length (L Tail) and Tail Moment (TM) values calculated by Comet Assay Software Project (CASP). The L Tail is the distance from the middle of nucleoid core to the end of the tail; TM is defined as the product of the percentage of DNA in the tail distribution and L Tail.

Data derived from three independent experiments, with at least 50 cells randomly scored per experiment (from two replicate slides

\section{Table 1}

Concentrations $(\mu \mathrm{M})$ of terpenes found in samples B and $C$ derived from the citrus transformation factory (2008).

\begin{tabular}{lllll}
\hline & $( \pm) \alpha$-Pinene & $(+) \beta$-Pinene & $(+) 3$-Carene & R-(+)limonene \\
\hline B & 0.4 & 3.6 & 0.75 & 1.36 \\
C & 0.02 & 0.02 & 0.007 & 0.12 \\
\hline
\end{tabular}

(B) Untreated and (C) treated wastewater.

each), were processed with the Kruskal-Wallis non-parametric statistical method.

\subsection{Photocatalytic experiments}

The photocatalytic experiments were carried out on treated (C) wastewater collected on 2010. Before the experiments the wastewater was filtered with $0.20 \mu \mathrm{m}$ filters (Millex, Millipore) and in order to remove the inorganic carbon, concentrated $\mathrm{H}_{2} \mathrm{SO}_{4}$ was added up to reach a $\mathrm{pH}$ of 4.5 . The photocatalytic runs were performed in a 0.151 Pyrex cylindrical batch photoreactor with an immersed lamp, continuously bubbling oxygen in the suspension and using an amount of $\mathrm{TiO}_{2}$ Degussa P25 (ca. 80\% anatase; $20 \%$ rutile, BET specific surface area: ca. $50 \mathrm{~m}^{2} \mathrm{~g}^{-1}$ ) equal to $0.4 \mathrm{~g} \mathrm{l}^{-1}$. Before starting the irradiation, the reacting suspension was magnetically mixed for ca. $30 \mathrm{~min}$ to achieve the adsorption/desorption equilibrium of the species contained into the solution. The suspensions were magnetically stirred throughout the runs and irradiated by a medium pressure $\mathrm{Hg}$ 125 W lamp (Helios Italquartz, Milano). The irradiance reaching the reacting suspension, measured in the wavelength range 320$390 \mathrm{~nm}$ with a UVX Digital radiometer, was ca. $10 \mathrm{~mW} \mathrm{~cm}^{-2}$. Due to the complexity of the solutions, only the total dissolved organic carbon (TOC) was analyzed. The analyses were performed at fixed intervals of time by using a Shimadzu 5000A instrument (error: $\pm 1 \mathrm{ppm}$ ), after separation of the photocatalyst from the suspension. The samples withdrawn at different time during the photocatalytic experiments were also subjected to Ames test.

\section{Results and discussion}

3.1. Biological effects of exposure of bacterial and mammalian cells to single terpenes or to the mixture of four terpenes

\subsubsection{Ames tests}

Ames tests with $S$. typhimurium strain TA100 were used to assess the mutagenic activity of single terpenes, i.e. $( \pm) \alpha$-pinene, $(+) \beta$-pinene, $(+) 3$-carene, and $\mathrm{R}-(+)$ limonene, or of the mixture of the four terpenes in the presence or absence of S9 mix. For this purpose, synthetic solutions of terpenes at the concentrations corresponding to those found in the wastewater $B$ (untreated) and $C$ (treated) sampled in 2008 [11] were utilized (Table 1).

As shown in Fig. 1, each terpene was not mutagenic in the presence and absence of 59 mix; indeed the number of revertants per plate was very close to the $100-200 / 10^{8}$ spontaneous revertants of strain TA100, according to the reports available on the investigation of the genotoxicity of such compounds individually. In fact, racemic mixtures of $\alpha$-pinene, such as $(+)$ and $(-)$ enantiomers of $\alpha$-pinene [22], or R-(+)limonene [23] have been previously shown to be not mutagenic in the Salmonella mutagenicity assay; no previous tests of $(+) 3$-carene or $(+) \beta$-pinene have been reported in the literature.

The negative results in the Ames test were consistent with our previous findings in V79 cells; in fact the exposure at a single terpene did not induce gene mutation [11].

Moreover we exposed concurrently S. typhimurium to synthetic solutions of the four terpenes in concentrations comparable to those found in the wastewater sampled in 2008 to study the cumulative effect, if any. Interestingly, the mixture of terpenes in the 

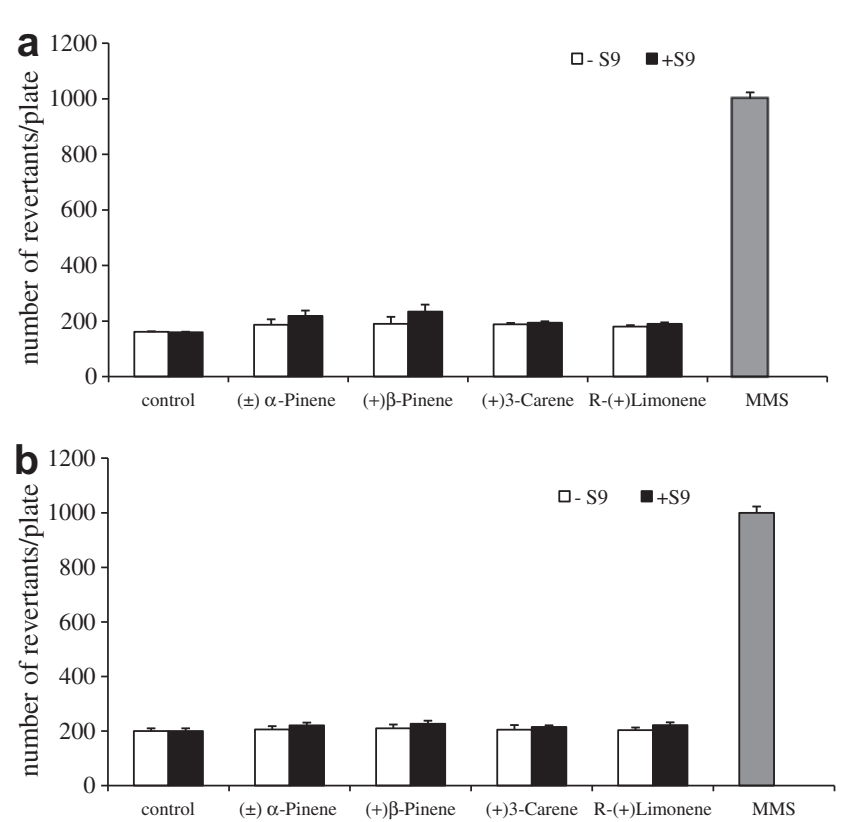

Fig. 1. Number of revertants/plate obtained after exposure to aqueous solutions of the single terpenes at concentration corresponding to those revealed in actual effluents B (a) and C (b) in the absence or in the presence of S9 mix. Control, i.e. untreated bacteria. MMS: positive control, i.e. bacteria treated with methyl methane sulfonate $(1 \mu \mathrm{g} /$ plate). Results from three experiments \pm S.D. are presented.

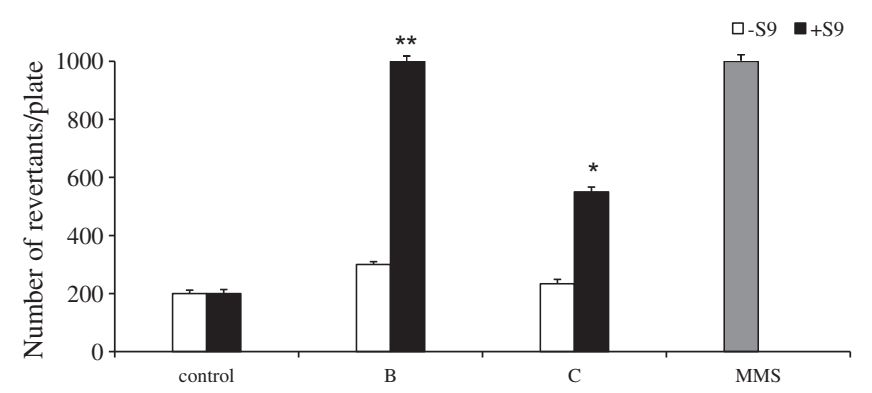

Fig. 2. Number of revertants/plate obtained after exposure to aqueous solutions of the mixture of the four terpenes at concentration corresponding to those revealed in actual effluents B and C in the absence or in the presence of S9. Control, i.e. untreated bacteria. MMS: positive control, i.e. bacteria treated with methyl methane sulfonate $(1 \mu \mathrm{g} /$ plate). Results from three experiments \pm S.D. are presented. ${ }^{*} p<0.001 v s$. control; ${ }^{* *} p<0.0001$ vs. control, according to the Student' $t$ test.

presence of S9 mix, induced a reproducible increase in the number of revertant colonies per plate; in particular, the increase induced by concurrent presence of synthetic solutions of terpenes at the concentrations corresponding to those found in the wastewater $\mathrm{B}$, was highly significant $(p<0.001)$ compared to the negative control values (Fig. 2). The results confirmed that the mixture of terpenes has mutagenic capability; in fact, we previously reported that the concurrent exposure to four terpenes affected the frequency of mutants at the hgprt locus in V79 Hamster cells [11]. However, terpenes mixture induces mutations in S. typhimurium only in the presence of a metabolic activation system (S9 mix). This result confirms that the biological effects of mixture of chemicals could be different from that of the single compounds and suggests that mutagenic metabolite/s can originate from the mixture during the phase I of the metabolism.

\subsubsection{Comet assay}

To evaluate the damage induced in V79 cells by exposure for $1 \mathrm{~h}$ to a single terpene or to a mixture of them, we used the Comet assay. Preliminary qualitative analyses, performed by classifying cells in three groups: undamaged-, damaged- and ghost-nucleus (Fig. 3), indicated that each terpene, at concentrations corresponding to those found in wastewater B (untreated) and C (treated) sampled in 2008 (Table 1), induced doses related DNA damage. In fact, DNA damage induced by single terpenes at concentrations corresponding to $\mathrm{B}$ (untreated wastewater) was significantly different $(p<0.001)$ in comparison to the control (Fig. 4a) and was higher than the damage induced by single terpenes at concentrations corresponding to $\mathrm{C}$ (treated wastewater). However, the level

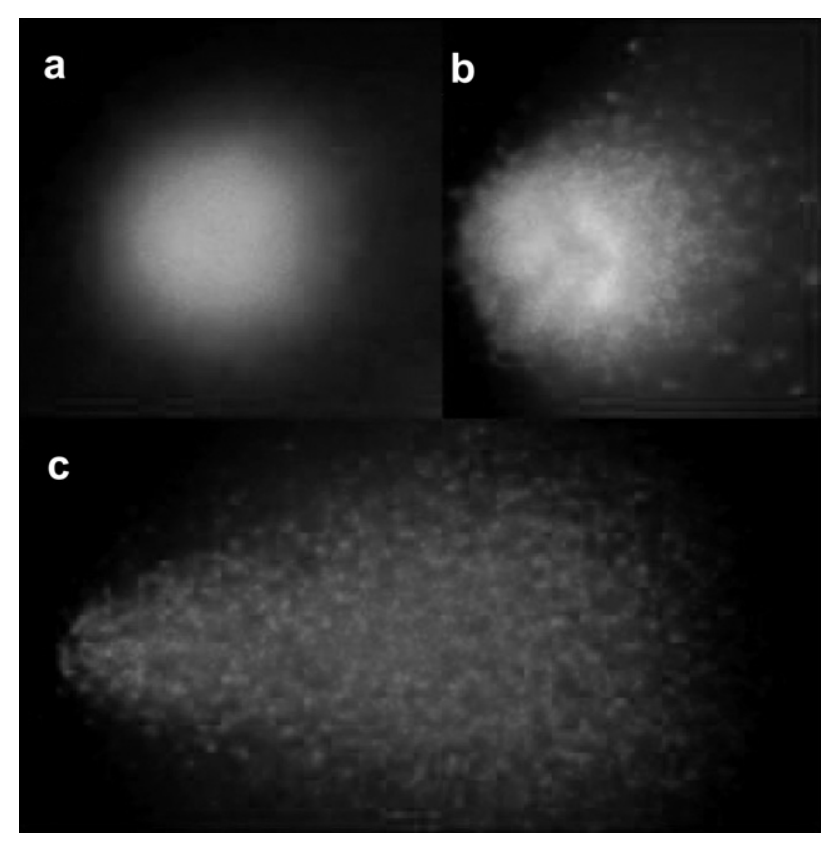

Fig. 3. Representative photomicrographs of undamaged- (a), damaged- (b) and ghost-nucleus taken with a fluorescence microscope at $100 \times$ magnification.
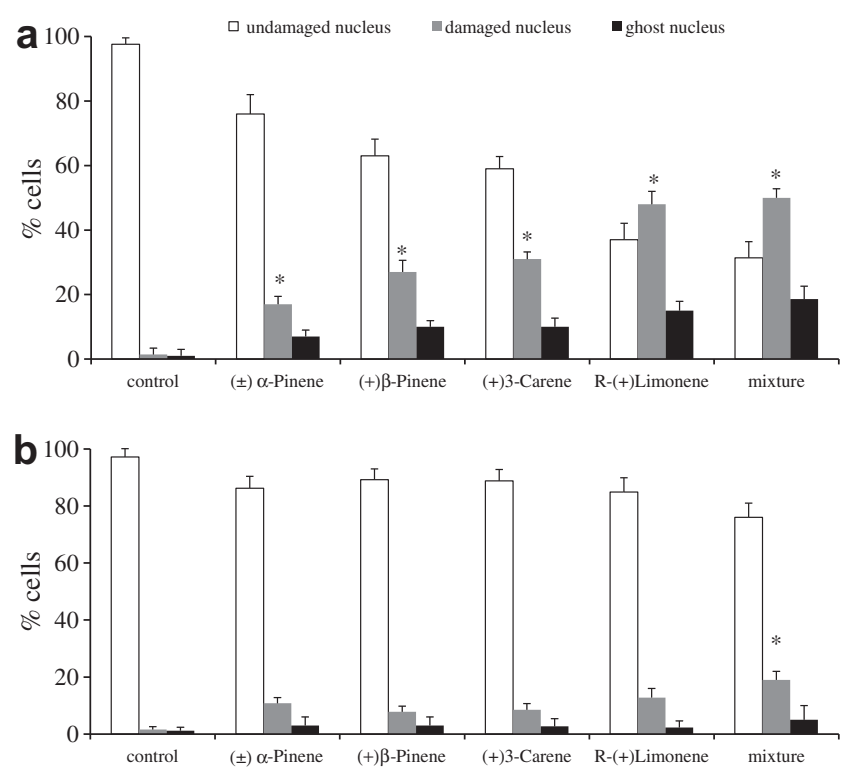

Fig. 4. Percentage of cells with undamaged-, damaged- and ghost-nucleus after exposure to aqueous solutions of the single terpenes or mixture of the four terpenes at concentrations corresponding to those revealed in actual effluents B (a) and C (b). Control, i.e. V79 Hamster Chinese cells untreated. Results from three experiments \pm S.D are presented. ${ }^{*} p<0.001 v$ s. control, according to the Student' $t$ test. 

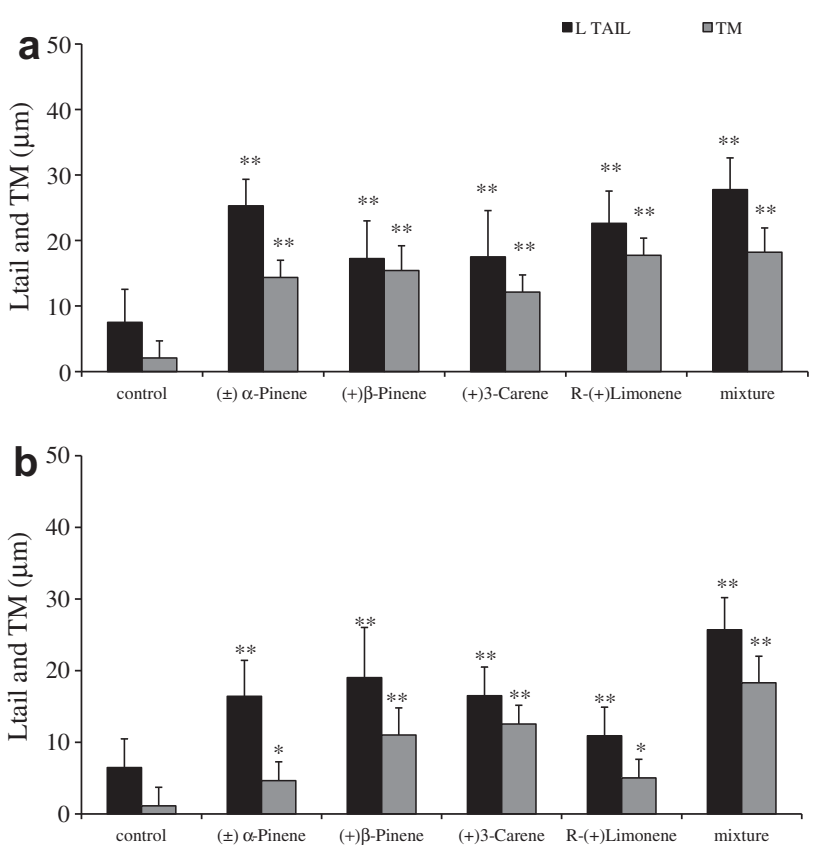

Fig. 5. $\mathrm{L}$ Tail and TM ( $\mu \mathrm{m})$ as a measure of DNA damage in the quantitative analysis of the Comet assay after exposure to aqueous solutions of the single terpenes or mixture of the four terpenes at concentrations corresponding to those revealed in actual effluents B (a) and C (b). Control, i.e. V79 Hamster Chinese cells untreated. Results from three experiments \pm S.D. are presented. ${ }^{*} p<0.001$ vs. control; ${ }^{* *} p<0.0001 v$ s. control, according to the Kruskal Wallis test.

of DNA damage induced by terpenes at concentrations of sample $C$ was higher than control values which were within historical records in our laboratory (Fig. 4b). Further, the frequency of damaged nuclei differed for each terpene tested.

The responses generated by concurrent exposure of cells to the four terpenes, at concentrations corresponding to B or C, confirmed that the frequency of damaged cells was significantly different with respect to the control, but it was lower than the sum of frequency of damaged cells induced by the single terpenes (Fig. 4a and $b$ ).

Quantitative evaluations, performed after treatment with single terpenes or mixture of the four terpenes at the concentrations corresponding to $\mathrm{B}$ or $\mathrm{C}$, revealed a highly significant $(p<0.0001)$ increase of the L Tail and TM in comparison to the control (Fig. 5a and $b$ ).

Results from both the qualitative and the quantitative analyses demonstrated, for the first time, that $( \pm) \alpha$-pinene, $(+) \beta$-pinene, $(+) 3$-carene, and $\mathrm{R}-(+)$ limonene are capable to cause damage to DNA. Moreover, it is worth to notice that the average of $L$ Tail values induced by the mixture of the four terpenes was lower than the sum of the average of L Tail values induced by the single terpenes. This result suggests that the concurrent presence of the four terpenes could induce the formation of cross-links; in fact, it is known that the presence of crosslinks would hamper the DNA breakage by the Comet [24].

\subsection{Biological effects of exposure of bacterial and mammalian cells to actual wastewater}

As scarce information is available about Citrus processing wastewater toxicity [4], we have also studied the biologic effects in bacterial and mammalian cells of the actual effluents.

Results obtained by exposure of $S$. typhimurium cells to 10,20 , 50 , and $100 \mu \mathrm{l} /$ plate of actual wastewater indicated that 50 and $100 \mu \mathrm{l}$ of wastewater $\mathrm{B}$ and $100 \mu \mathrm{l}$ of wastewater $\mathrm{C}$ induced a

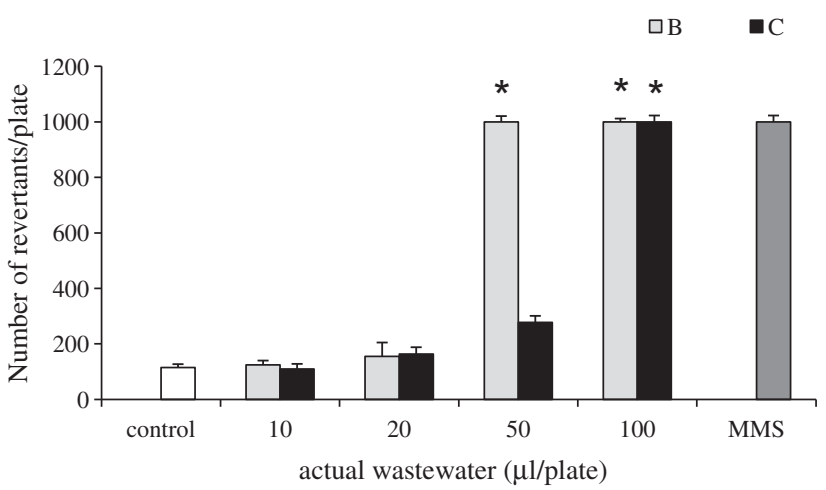

Fig. 6. Number of revertants/plate obtained after exposure to different amounts of actual wastewater B and C. Control, i.e. untreated bacteria. MMS: positive control, i.e. bacteria treated with methyl methane sulfonate $(1 \mu \mathrm{g} /$ plate). Results from three experiments \pm S.D. are presented. ${ }^{*} p<0.0001 v$ s. control, according to the Student' $t$ test.
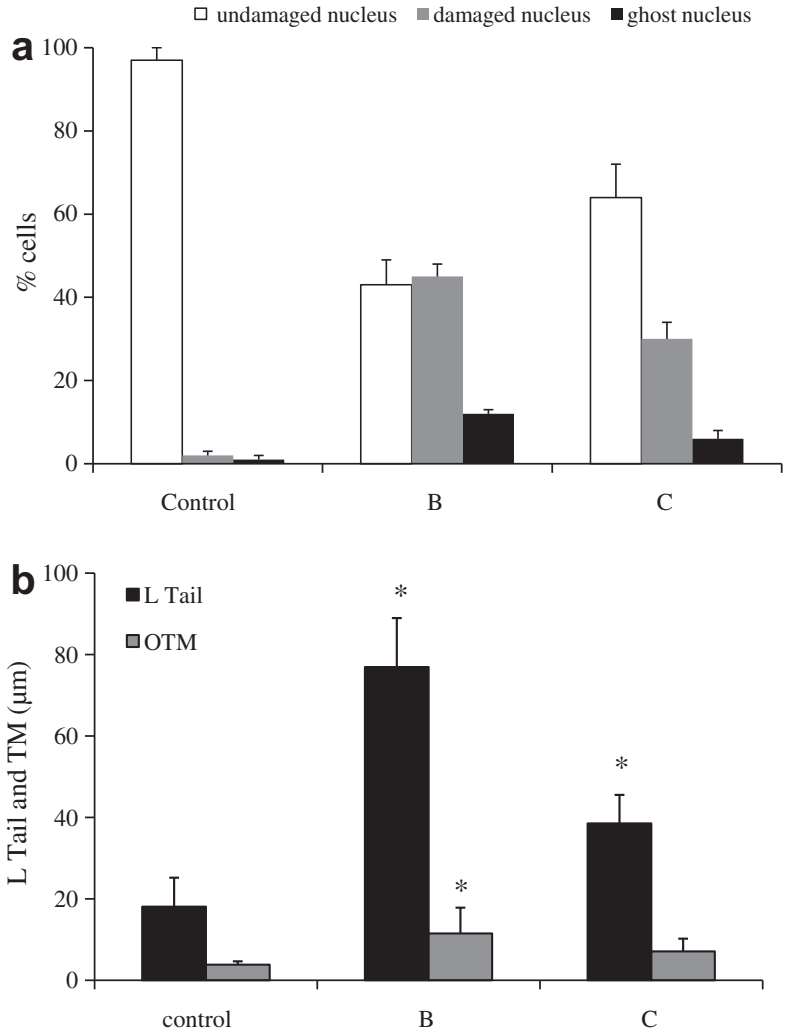

Fig. 7. Percentage of cells with undamaged-, damaged- and ghost-nucleus (a) and L Tail and TM (b) after exposure to $100 \mu \mathrm{l} /$ plate of actual effluents B and C. Results from three experiments \pm S.D. are presented. ${ }^{*} p<0.0001 v$ s. control, according to the Kruskal Wallis test.

highly significant $(p<0.0001)$ number of revertants with comparison to the control (Fig. 6).

The DNA damage induced by these effluents to mammalian cells was indicated by results obtained from Comet assay. The qualitative analyses indicated that $45 \%$ and $30 \%$ of V79 cells, treated for $1 \mathrm{~h}$ with $100 \mu \mathrm{l}$ of actual wastewater B or C, respectively, were damaged (Fig. 7a). In addition significant increases $(p<0.0001)$ in L Tail and TM were detected (Fig. 7b). It is evident that the actual effluents were genotoxic for both the biological systems. 


\subsection{HS-SPME-GC/MS}

Gas chromatographic (GC) methods have been extensively applied in this field, in connection often with mass spectrometric (MS) analysis, to detect by the headspace method the composition of the volatile components of water and wastewater [25,26]. Linear retention indices (LRI) were calculated using Kovats' equation [27] with the sequence of linear hydrocarbons from C10 to C26. HSSPME-GC/FID analyses of microfiltered wastewater C (treated) indicated that the concentrations of the four terpenes were below the limits of determination. Preliminary qualitative analysis by HSSPME-GC/MS showed that other volatile compounds, as eucalyptol, citronellol and trans-geraniol, were present (Fig. 8). It has been reported that the non-cyclic terpene alcohols citronellol and transgeraniol are inactive in bacterial and mammalian cell systems [28] while the literature data on mutagenic and genotoxic effects of eucalyptol are controversial [29].

Volatile compounds of microfiltered wastewater $C$ were identified first by a critical and reasoned comparison with mass spectral data within the NIST 2005 library. Subsequently compounds listed were verified on the LRI list. In addition, compounds were compared to their related standards.

Of course, in addition to the volatile compounds detected, it cannot be excluded the presence of other soluble substances that are responsible of the genotoxicity of wastewater and notably traces of other molecules as for instance, Copaene, $\alpha$-Bergamotene, Caryophyllene and Valencen (all sesquiterpenes), were found in unfiltered wastewater $C$. It has been reported that sesquiterpenes are present in citrus essential oil [30,31]; no cytotoxicity or mutagenicity in a large range of concentrations was observed by Gonçalves et al. [32], but the authors did not exclude the possibility that the bioactivity of the chemicals in a mixture could be different from that of the isolated compounds. Moreover cytotoxic and genotoxic activity of P. gaudichaudianum essential oil has been attributed to $\alpha$-humulene and (E)-caryophyllene sesquiterpenes [33]; on the contrary, anticlastogenic activity of $\beta$-caryophyllene has been reported [34].

\subsection{Photocatalytic experiments}

The photocatalytic technology represents an advanced oxidation technology suitable to degrade almost all types of organic pollutants dissolved in water. The most used photocatalyst is polycrystalline $\mathrm{TiO}_{2}$ in the anatase form, due to its low cost, insolubility in water and nontoxicity. When aqueous suspensions of this

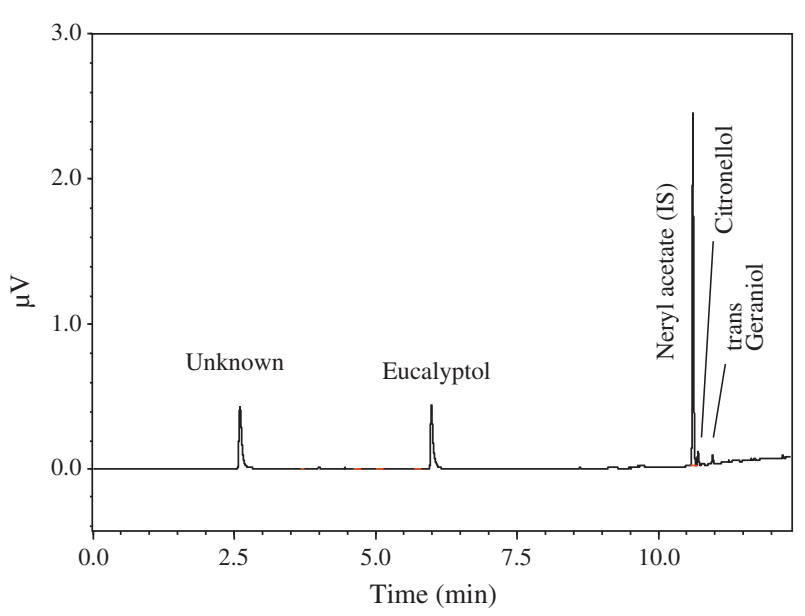

Fig. 8. Chromatogram of microfiltered wastewater C (treated) by HD-SPME-GC/MS analysis. semiconductor are irradiated, at the solid-liquid interface a great variety of photoinduced chemical reactions, able to degrade the organic molecules present, can occur by means of formation of very reactive radical species that are generated in the presence of $\mathrm{O}_{2}$ and $\mathrm{H}_{2} \mathrm{O}$. Reactions (1)-(7) show some events that can occur after the photoproduction of electrons and holes in the conduction (CB) and valence band $(\mathrm{VB})$, respectively:

$$
\begin{aligned}
& \mathrm{TiO}_{2}+\mathrm{h} v \rightarrow \mathrm{TiO}_{2}\left(\mathrm{e}_{(\mathrm{CB})}^{-}+\mathrm{h}_{(\mathrm{VB})}^{+}\right) \\
& \mathrm{OH}^{-}+\mathrm{h}_{(\mathrm{VB})}^{+} \rightarrow \cdot \mathrm{OH} \\
& \mathrm{O}_{2}+\mathrm{e}_{(\mathrm{CB})}^{-} \rightarrow \cdot \mathrm{O}_{2}^{-} \\
& \cdot \mathrm{O}_{2}^{-}+\mathrm{H}^{+} \rightarrow \cdot \mathrm{HO}_{2} \\
& 2 \cdot \mathrm{HO}_{2} \rightarrow \mathrm{O}_{2}+\mathrm{H}_{2} \mathrm{O}_{2} \\
& \mathrm{H}_{2} \mathrm{O}_{2}+\mathrm{O}_{2}^{-} \rightarrow \mathrm{OH}^{-}+\cdot \mathrm{OH}+\mathrm{O}_{2}
\end{aligned}
$$

Terpene + radical species (for instance $\left.\cdot \mathrm{OH} ; \mathrm{O}_{2}^{-}\right) \rightarrow \mathrm{H}_{2} \mathrm{O}+\mathrm{CO}_{2}$

Some preliminary blank tests indicated that no reactivity occurs in runs performed under the same experimental conditions used for the photo-reactivity experiments but in the absence of catalyst, oxygen or light. It was concluded that the simultaneous presence of $\mathrm{O}_{2}$, catalyst and irradiation is needed for the occurrence of the degradation process of the organic compounds present in the industrial wastewater. The photocatalytic runs were carried out by using the actual wastewater (sample $C$, treated wastewater). In Fig. 9 the Total Organic Carbon concentration (TOC) vs. irradiation time is reported for a representative run. The disappearance in ca. $5 \mathrm{~h}$ of the organic carbon (the residual TOC was ca. $1 \mathrm{mg} \mathrm{l}^{-1}$, i.e. in the experimental error of the instrument) indicated that in this actual situation the photocatalytic technology can be applied for the complete mineralization of the several pollutants present in the treated wastewater ( $C$ sample). Results obtained by exposure of $S$. typhimurium cells to sample $C$ before and during the photocatalytic treatment are also reported in Fig. 9. The samples collected from 0 to $2 \mathrm{~h}$ of irradiation showed genotoxic capability: in fact they induced a significant increase of revertants per plate.

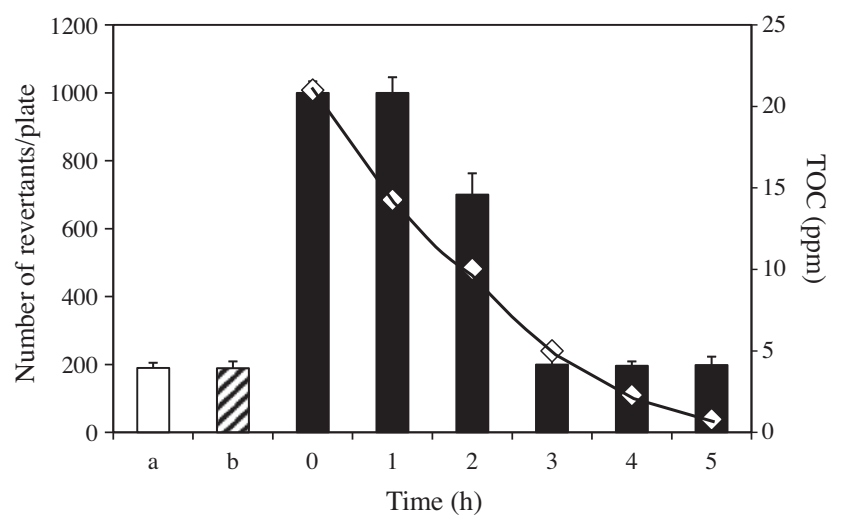

Fig. 9. TOC $(\diamond)$ concentration (ppm) vs. irradiation time $(\mathrm{h})$ during a photocatalytic test of actual wastewater C. Histograms indicate the number of revertants/plate obtained after exposure to sample withdrawn at different irradiation time during the same photocatalytic run. (a) Untreated bacteria; (b) bacteria treated with $\mathrm{TiO}_{2}$. 
The samples, subsequently collected, lose this capability; in fact these samples induced a number of revertants per plate very close to $100-200 / 10^{8}$ spontaneous revertants of strain TA100.

Notably they were completely degraded at the end of the photocatalytic treatment because the number of revertants per plate returned down to the spontaneous background.

\section{Conclusion}

The composition of citrus transformation plant wastewater is highly complex and the terpenes constitute a relevant organic load. So, initially we have addressed our interest to evaluate the biological effects in bacterial and mammalian cells of $( \pm) \alpha$-pinene, $(+) \beta$-pinene, $(+) 3$-carene, and R-(+)limonene, found in high concentrations in actual industrial effluents and still present in industrial wastewater after the biological treatment.

The single terpenes resulted not mutageneic in S. thyphimurium, but they were capable to induce DNA damage in mammalian cells. This result is the first experimental evidence that these terpenes affect the integrity of genome. To-date, we do not know if the DNA damage is the result of direct genotoxicity or it is related to an indirect effect, i.e. the terpenes capability of inducing reactive oxygen species. This is possible by considering that this capability was demonstrated by Singh et al. for $\alpha$-pinene [35]. The mixture of four terpenes resulted strongly mutagenic in bacterial cells, and it was able to induce DNA damage in mammalian cells also at the lowest concentrations. The response obtained in concurrent treatments could be the result of some sort of interaction between the four terpenes or simply an additive effect.

Both hypotheses are plausible, but they must be corroborated by specifically designed experiments to clarify the joint chemical action of the four monoterpenes (individually considered as safe substances) able to induce DNA damage when they are contemporaneously present.

As a new finding the actual wastewater was found higly genotoxic in bacterial and mammalian cells. This result indicates that the industrial biological treatment is partially effective. On the contrary, the photocatalytic technology was effective for the complete mineralization of the several pollutants present in the treated wastewater. Moreover the samples collected after two hours of irradiation lose genotoxic capability, indicating that the transformation/mineralization of the starting organic compounds is beneficial with respect to the genotoxicity of the wastewater.

\section{Acknowledgment} Italy.

This work was supported by the University of Palermo, Palermo,

\section{References}

[1] A.G. Lane, Anaerobic digestion of orange peel, Food Technol. Aust. 36 (1984) 125-127.

[2] M.W. Ratcliff, Citrus Processing Waste Prevention, Handling and Treatment, Citrus World, Lake Wales, Florida, USA, 1990.

[3] D.A. Kimball, Citrus Processing. Quality Control and Technology, AVI Book, New York, USA, 1999.

[4] I. Karaouzas, E. Cotou, T.A. Albanis, A. Kamarianos, N.T. Skoulikidis, U. Giannakou, Bioassays and biochemical biomarkers for assessing olive mill and citrus processing wastewater toxicity, Environ. Toxicol. 26 (2011) 669676.

[5] E. Pichersky, J. Gershenzon, The formation and function of plant volatiles: perfumes for pollinator attraction and defence, Curr. Opin. Plant Biol. 5 (2002) 237-243.

[6] F. Loreto, P. Pinelli, F. Manes, H. Kollist, Impact of ozone on monoterpene emissions and evidence for an isoprene-like antioxidant action of monoterpenes emitted by Quercus ilex leaves, Tree Physiol. 24 (2004) 361367.
[7] T.D. Sharkey, S. Yeh, Isoprene emission from plants, Annu. Rev. Plant Physiol. Plant Mol. Biol. 52 (2001) 407-436.

[8] J.A. Buhagiar, M.T. Podesta, A.P. Wilon, M. Micallef, S. Ali, The induction of apoptosis in Human melanoma, breast and ovarian cancer cell lines using an essential oil extract from the conifer Tetraclinis articulate, Anticancer Res. 19 (1999) 5435-5443.

[9] J.R. Lazutka, J. Mierauskiene, G. Slapšyte, V. Dedonyte, Genotoxicity of dill (Anethum graveolens L.), peppermint (Menthaxpiperita L.) and pine (Pinus sylvestris L.) essential oils in human lymphocytes and Drosophila melanogaster, Food Chem. Toxicol. 39 (2001) 485-492.

[10] H.F. Mark, R. Naram, J.T. Singer, R.W. Rice, W.C. Bastan, L.J. Beauregard, P.H Lamarche, Wood-drying condensate from Eastern white pine induced cytotoxicity and genotoxicity in vitro, Ann. Clin. Lab. Sci. 26 (1996) 64-70.

[11] I. Catanzaro, G. Avellone, G. Marcì, M. Saverini, L. Scalici, G. Sciandrello, L. Palmisano, Biological effects and photodegradation by $\mathrm{TiO}_{2}$ of terpenes present in industrial wastewater, J. Hazard. Mater. 185 (2011) 591-597.

[12] V. Augugliaro, V. Loddo, G. Marcì, L. Palmisano, M.J. López-Muñoz, Photocatalytic oxidation of cyanides in aqueous titanium dioxide suspensions, J. Catal. 166 (1997) 272-283.

[13] G. Marcì, A. Di Paola, E. García-López, L. Palmisano, Photocatalytic oxidation mechanism of benzonitrile in aqueous suspensions of titanium dioxide, Catal. Today 129 (2007) 16-21.

[14] J. Matos, E. García-López, L. Palmisano, A. García, G. Marcì, Influence of activated carbon in $\mathrm{TiO}_{2}$ and $\mathrm{ZnO}$ mediated photo-assisted degradation of 2propanol in gas-solid regime, Appl. Catal., B 99 (2010) 170-180.

[15] J. Pawliszyn (Ed.), Applications of Solid Phase Microextraction, Royal Society of Chemistry, Cambridge, UK, 1999.

[16] G. Vas, K. Vekey, Solid-phase microextraction: a powerful sample preparation tool prior to mass spectrometric analysis, J. Mass Spectrom. 39 (2004) 233254.

[17] D. Zuba, A. Parczewski, M. Reichenbächer, Optimization of solid phase microextraction conditions for gas chromatographic determination of ethanol and other volatile compounds in blood, J. Chromatogr. B 773 (2002) 75-82.

[18] S. Hamm, E. Lesellier, J. Bleton, A. Tchapla, Optimization of headspace solid phase microextraction for gas chromatography/mass spectrometry analysis of widely different volatility and polarity terpenoids in olibanum, J. Chromatogr. A 1018 (2003) 73-83.

[19] M.J. Cantavenera, I. Catanzaro, V. Loddo, L. Palmisano, G. Sciandrello, Photocatalytic degradation of paraquat and genotoxicity of its intermediate products, J. Photochem. Photobiol., A 185 (2007) 277-282.

[20] N.P. Singh, M.T. McCoy, A simple technique for quantization of low levels of DNA damage in individual cells, Exp. Cell Res. 175 (1988) 184-191.

[21] R.R. Tice, E. Agurell, D. Anderson, B. Burlinson, A. Hartmann, H. Kobayashi, Y. Miyamae, E. Rojas, J.C. Ryu, Y.F. Sasaki, Single cell gel/Comet assay: guideline for in vitro and in vivo genetic toxicology testing, Environ. Mol. Mutagen. 35 (2000) 206-221.

[22] M.R. Gomes-Carneiro, M.E.S. Viana, I. Felzenszwalb, F.J.R. Paumgartten, Evaluation of $\beta$-myrcene, $\alpha$-terpinene and $(+)$ - and $(-)$ - $\alpha$-pinene in the Salmonella/microsome assay, Food Chem. Toxicol. 43 (2005) 247-252.

[23] J. Whysner, G.M. Williams, d-Limonene mechanistic data and risk assessment: absolute species-specific cytotoxicity, enhanced cell proliferation, and tumor promotion, Pharmacol. Ther. 71 (1996) 127-136.

[24] P.L. Olive, J.P. Banáth, The Comet assay: a method to measure DNA damage in individual cells, Nat. Protoc. 1 (2006) 23-26.

[25] A. Godayol, M. Alonso, E. Besalú, J.M. Sanchez, E. Anticó, Odour-causing organic compounds in wastewater treatment plants: evaluation of headspace solidphase microextraction as a concentration technique, J. Chromatogr. A 1218 (2011) 4863-4868.

[26] G. Pecoraino, L. Scalici, G. Avellone, L. Ceraulo, R. Favara, E. Gagliano Candela, M.C. Provenzano, C. Scaletta, Distribution of volatile organic compounds in sicilian ground waters analysed by head space solid phase micro extraction coupled with gas chromatography mass spectrometry (SPME/GC/MS), Water Res. 42 (2008) 3563-3577.

[27] E.S. Kovatz, Gas chromatographic characterization of organic compounds. L retention index of aliphatic halides, alcohols, aldehydes, and ketones, Helv. Chim. Acta 6 (1958) 1915-1932.

[28] D. Belsito, D. Bickers, M. Bruze, P. Calow, H. Greim, J.M. Hanifin, A.E. Rogers, J.H. Saurat, I.G. Sipes, H. Tagami, A toxicologic and dermatologic assessment of cyclic and non-cyclic terpene alcohols when used as fragrance ingredients, Food Chem. Toxicol. 46 (2008) 51-57.

[29] B. Nikolić, D. Mitic-Ćulafíc, B. Vukovic-Gačić, J. Kneževic-Vukčević, Modulation of genotoxicity and DNA repair by plant monoterpenes camphor, eucalyptol and thujone in Escherichia coli and mammalian cells, Food Chem. Toxicol. 49 (2011) 2035-2045.

[30] C. Ragonese, D. Sciarrone, P.Q. Tranchida, P. Dugo, G. Dugo, L. Mondello, Evaluation of a medium-polarity ionic liquid stationary phase in the analysis of flavor and fragrance compounds, Anal. Chem. 83 (2011) 7947-7954.

[31] E. González-Molina, R. Domínguez-Perles, D.A. Moreno, C. García-Viguera, Natural bioactive compounds of Citrus limon for food and health, J. Pharm. Biomed. Anal. 51 (2010) 327-345.

[32] O. Gonçalves, R. Pereira, F. Gonçalves, S. Mendo, M.A. Coimbra, S.M. Rocha Evaluation of the mutagenicity of sesquiterpenic compounds and their influence on the susceptibility towards antibiotics of two clinically relevant bacterial strains, Mutat. Res. 723 (2011) 18-25. 
[33] V.F. Péres, D.J. Moura, A.R.M. Sperotto, F.C. Damasceno, E.B. Caramão, C.A. Zini, J. Saffi, Chemical composition and cytotoxic, mutagenic and genotoxic activities of the essential oil from Piper gaudichaudianum Kunth leaves, Food Chem. Toxicol. 47 (2009) 2389-2395.

[34] A. Di Sotto, G. Mazzanti, F. Carbone, P. Hrelia, F. Maffei, Inhibition by $\beta$-caryophillene of ethyl methanesulfonate-induced clastogenicity in cultured human lymphocytes, Mutat. Res. 699 (2010) 23-28.
[35] H.P. Singh, D.R. Batish, S. Kaur, K. Arora, R.K. Kohli, Alpha-pinene inhibits growth and induces oxidative stress in roots, Ann. Bot. 98 (2006) 1261-1269. 